\title{
Uma alternativa para escapar à tabloidização ou uma forma de tabloidização alternativa? O mercado brasileiro de jornais populares e a economia política da imprensa escrita ${ }^{2}$
}

\section{An alternative to escape tabloidization or an alternative form of tabloidization? \\ Brazilian popular newspaper market and the political economy of printed press}

As manchetes são curiosas e divertidas, mas o jornalismo sensacionalista e despretensioso é controverso, e, muitas vezes, apontado como alienante. Os tabloides têm ganhado espaço no mercado da imprensa escrita brasileira nos últimos anos, e há quem aposte no gênero como modelo inexorável de desenvolvimento futuro do jornalismo, particularmente no que tange ao conteúdo textual reduzido e ao visual apelativo. Em princípio, costuma-se avaliar como mínima ou nenhuma a cobertura cotidiana ${ }^{3}$ de temas políticos ou da economia no noticiário dos tabloides (Sparks e Dalhgren, 1992). Em contrapartida, abundam temas relacionados a escândalos, crimes, sexo e

\footnotetext{
1 É professor no Departamento de Estudos Culturais e Mídia e no Programa de Pós-Graduação em Comunicação da Universidade Federal Fluminense (UFF).E-mail:<viktor@midia.uff.br>.

2 Uma versão preliminar deste artigo foi apresentada no Grupo de Trabalho "Mídia, Política e Eleições", do $38^{\circ}$ Encontro Anual da Associação Nacional de Pós-Graduação e Pesquisa em Ciências Sociais (Anpocs), em Caxambu (MG). A pesquisa é apoiada com recursos da Chamada UniversalCNPq nº 14/2013 e conta com dados gentilmente fornecidos pelo Instituto Brasileiro de Opinião Pública e Estatística (Ibope), pelo Instituto Verificador de Comunicação (IVC) e pelo Meio \& Mensagem, instituições às quais agradecemos a colaboração.

3 Excetuando-se, logicamente, temas que remetem aos escândalos políticos ou às situações fora do comum, como o recente falecimento do candidato à Presidência da República Eduardo Campos, noticiado, ainda que brevemente, em jornais do gênero. 
esportes. Por essa razão, analistas de mídia não hesitam em estabelecer comparações alarmantes entre o jornalismo praticado nas páginas de tabloides e aquele publicado pela imprensa de prestígio. Os termos desta comparação fundamentam leituras de que os tabloides influenciam os demais jornais tanto em sua cobertura noticiosa quanto em seu estilo peculiar. Em torno desse efeito arregimentou-se a literatura acadêmica que trata do fenômeno da "tabloidização".

$\mathrm{Na}$ virada da década de 1990 para os anos 2000, a discussão sobre a "tabloidização" das imprensas europeia e norte-americana tomou de assalto a pesquisa sobre jornalismo. Sobretudo a partir dos trabalhos basilares de Esser (1999), Sparks (1998) e Sparks e Tulloch (2000), que delimitaram as fronteiras conceituais da expressão, muito se debateu a respeito de uma perigosa contaminação da imprensa prestigiosa por uma eventual "agenda tabloide", modo que o jornalismo popular era geralmente evocado como um vilão indefectível do rigor da imprensa. Mais recentemente, o trabalho de outros pesquisadores -como Wasserman (2010) e Ranganathan e Rodrigues (2010), mais alinhados com uma perspectiva de diálogo Sul-Sul - tem procurado chamar a atenção para o papel dos tabloides na economia política do jornalismo, apontando para o modelo de negócios desses veículos como possível chave para a crise enfrentada pela imprensa escrita nos países desenvolvidos. Fato é que países como Índia - objeto de Ranganathan e Rodrigues (2010) -, África do Sul - objeto de Wasserman (2010) -e Brasil têm se destacado entre raras exceções ao cenário de recessão econômica que encaram jornais em todo o mundo. Diferentemente dos dois primeiros, contudo, o Brasil tem apostado em modelo econômico diverso, que, por vezes, justapõe veículos de prestígio e tabloides como aliados e não competidores, como temos apontado (Chagas, 2013; 2014a; 2014b; Lattman-Weltman e Chagas, 2013). Há, apesar disso, pouca pesquisa sobre o tema.

A proposta deste trabalho, portanto, compreende: a) um investimento teórico na empregabilidade da categoria "tabloide" e no processo descrito pela noção de "tabloidização" ao cenário brasileiro; b) a análise e o subsequente aprofundamento das questões 
econômicas inerentes ao jornalismo popular no Brasil, sua expansão/ seu avanço e eventuais riscos relacionados à concorrência com outros gêneros; c) a proposição de uma agenda de pesquisa para o desenvolvimento de um modelo metodológico-epistemológico com vistas à identificação e à distinção de tabloides e quality papers; e, finalmente, d) a proposição de um breve debate sobre o espaço ocupado pela política e outras editorias no noticiário popular nacional.

Para apresentarmos de maneira consistente essas questões, procuramos dividir este artigo em quatro seções: na primeira, trataremos de desenvolver uma revisão da literatura sobre o tema da "tabloidização" em suas diferentes abordagens. Logo após, discorreremos sobre a adaptação da categoria à realidade brasileira. Mais adiante, em função do debate expresso nas seções anteriores, desenvolveremos uma proposta epistemológica que visa precisar a identificação e uniformizar a adoção terminológica de diferentes chaves, como "tabloides" e "jornais populares”, ou, ainda, "quality papers". Por fim, tomando como base dados de pesquisas recentes divulgadas pela Secretaria de Comunicação Social (Secom) do governo federal e outras fontes de importância similar, procuraremos mapear o espaço ocupado pelo jornalismo tabloide na economia da imprensa nacional e, em especial, no cenário político do país.

Nossa hipótese principal de pesquisa é de que as empresas de comunicação no Brasil, especialmente as proprietárias de jornais impressos, procuraram desenvolver uma solução alternativa para a crise pela qual passa o jornalismo em diferentes países, ancorada na propriedade cruzada dos meios e no prestígio acumulado por seus títulos de referência nacional. Neste sentido, os reflexos do processo descrito por diversos estudiosos europeus e norte-americanos como "tabloidização", nos anos 1990, têm sido experimentados de forma razoavelmente distinta pelo público nacional. Como efeito disso, o Brasil, junto da Índia, da África do Sul, da China e de mais outros poucos países, tem lidado com uma expansão no mercado e nos índices de circulação dos jornais impressos que não encontra paralelo nos países do Norte. Apesar disso, esta expansão está concentrada no segmento de jornais populares e tabloides, de modo que os grandes jornais do país não estão completamente livres da crise que abala o mercado internacional. 
Nas páginas seguintes, procuramos explorar o significado dessa "tabloidização" alternativa e abordar em detalhes como o mercado de jornais populares tem se constituído no Brasil nos últimos anos à margem dos grandes anunciantes e investidores privados. Com base nos dados de faturamento de diferentes veículos, nossa principal expectativa é responder à questão norteadora deste trabalho sobre quais são as peculiaridades do processo de tabloidização no Brasil e do modelo econômico da imprensa escrita nacional, unindo a esta uma outra questão fundamental e mais abrangente, objeto de nossa pesquisa em seu sentido ampliado, sobre de que forma o mercado brasileiro tem experimentado a crise de naturezas política e econômica pela qual a imprensa internacional tem passado.

\section{Ameaça ou revolução? A primeira geração de estudos sobre o fenômeno da "tabloidização" nos anos 1990}

Os estudos sobre o fenômeno da "tabloidização" floresceram há cerca de 20 anos na Europa e nos Estados Unidos, e, desde então, têm sido esparsamente revisitados, particularmente por pesquisadores que se ocupam do aprimoramento e da profissionalização da imprensa em países em desenvolvimento. Esse movimento, ao mesmo tempo em que aponta um deslocamento do eixo de análise na pesquisa acadêmica, parece também indicar que as preocupações em se estudar o fenômeno na Europa Ocidental e nos Estados Unidos foram razoavelmente esgotadas nas últimas décadas. Ainda assim, é a literatura de fins da década de 1990 que, em grande medida, segue apontando os caminhos conceituais a novos pesquisadores sobre o tema. Entre os principais trabalhos tomados como ponto de partida para essas análises, é rotineira a presença de referências a Esser (1999), Sparks (1998) e Sparks eTulloch (2000).

Nessa cronologia, um dos primeiros volumes a tratar do tema diretamente foi arregimentado por Colin Sparks (1998) em meio a um dossiê do periódico esloveno Javnost - The Public. Com textos de Ian Connell, Elizabeth S. Bird, Kaori Hayashi, Agnes Gulyas, Ulrike Klein, Dick Rooney, Mira MacDonald e do próprio Sparks, a edição foi precursora ao propor uma abordagem supranacional e de abrangência disciplinar 
variada, englobando estudos que passavam em revista os Estados Unidos, a Alemanha, o Japão, a Grã-Bretanha e a Hungria. Alguns deles, em conjunto com outros trabalhos, foram republicados em seguida na coletânea que Sparks assinou com o professor John Tulloch (2000), intitulada Tabloid Tales e que constitui hoje leitura indispensável para os estudiosos da área. Antes ainda, Sparks havia organizado com Peter Dalhgren (1992) uma outra antologia sobre jornalismo e cultura popular, na esteira de pesquisas que vinham se desenvolvendo sobre essa linha, como as obras de Kurtz (1993) e Fiske (2011).

Em paralelo, outros estudiosos destacam-se à mesma altura. $\mathrm{Na}$ Alemanha, Esser (1999) buscou indicar, por meio de uma análise comparativa entre as realidades da imprensa germânica e da imprensa britânica, como ocorria a evolução dos periódicos impressos nos dois países e, além disso, como mudava, em decorrência do fenômeno da "tabloidização", a percepção do jornalista sobre seu ethos. Apresentando-a como um processo em que os chamados quality papers eram contaminados por uma "agenda tabloide", em que se minimizavam os temas políticos em relação à exploração de uma cobertura sensacionalista, repleta de escândalos, Esser (op. cit.) argumentava que, para melhor compreender os efeitos deste processo, seria mais frutífero que se estudasse a imprensa de qualidade, não a imprensa tabloide, uma vez que na primeira é que se encontrariam os elementos da crise anunciada. Esser (op. cit.) procura distinguir o formato tabloide 4 do gênero tabloide, e diferencia, na esteira de Sparks (1998; 2000) e Sparks e Dalhgren (1992), o tabloide europeu diário do semanário norte-americano vendido em supermercados. Tal operação resulta na proposta de que a "tabloidização" seria um processo que, como tal, toma lugar no tempo, e implica uma contaminação da mídia "séria" por uma perspectiva e um estilo próprios do jornalismo popular. Na concepção de Esser, a tabloidização implica um movimento em que a mídia mainstream é "tabloidizada" pela influência de uma dinâmica

4 Segundo Esser (1999), o termo "tabloide" origina-se ainda na primeira metade do século XX e faz referência a uma marca de fármacos em forma concentrada de pílulas ou tabletes. "O efeito narcotic do tabloide e o fato de que ele seria fácil de engolir foram prontamente transferidos para o meio de comunicação" (ibidem, p. 292). 
competitiva por popularidade. Fatores econômicos, concorrência e fatores legais (a proteção à privacidade, por exemplo) estão entre as principais características desse cenário. Este processo, no entanto, não ocorreria de maneira uniforme internacionalmente e deveria ser, justamente por isso, estudado sempre em abordagens multidimensionais, em especial por se tratar de um conceito ainda "vago" (Esser, 1999, p. 293-294).

O estudo de Esser (1999) abriu as portas para o lançamento da coletânea de Sparks e Tulloch (2000), com artigos seminais sobre a questão. No capítulo que descerra esta mesma coletânea, Sparks desenvolve uma metodologia própria para avaliação do fenômeno da "tabloidização". Seguindo a escala proposta por Sparks (2000, p. 12-15) é possível reconhecer níveis distintos de "tabloidização" arranjados em um gráfico cartesiano que considera como eixo horizontal a concentração do noticiário de um dado meio na cobertura sobre política, economia ou sociedade de um lado, e escândalos, esportes e entretenimento de outro, e, como eixo vertical, a concentração na vida pública em oposição à concentração na vida privada. O resultado é o que se segue.

No espectro proposto por Sparks (ver figura 1) são apresentadas as bases para a distinção que Gripsrud (2000), mais adiante no mesmo volume, sugere, segundo a qual nem todo jornalismo popular deve ser encarado como tabloide. No modelo de Gripsrud (ver figura 2), menos do que um gráfico cartesiano, o que temos são padrões concêntricos, que abarcam o jornalismo popular, o jornalismo efetivamente tabloide e o por ele denominado jornalismo trash, uma vertente ainda mais radical no que tange ao sensacionalismo e ao desvirtuamento da imprensa de seu aspecto público. 
Figura 1 - Tipologia de Sparks

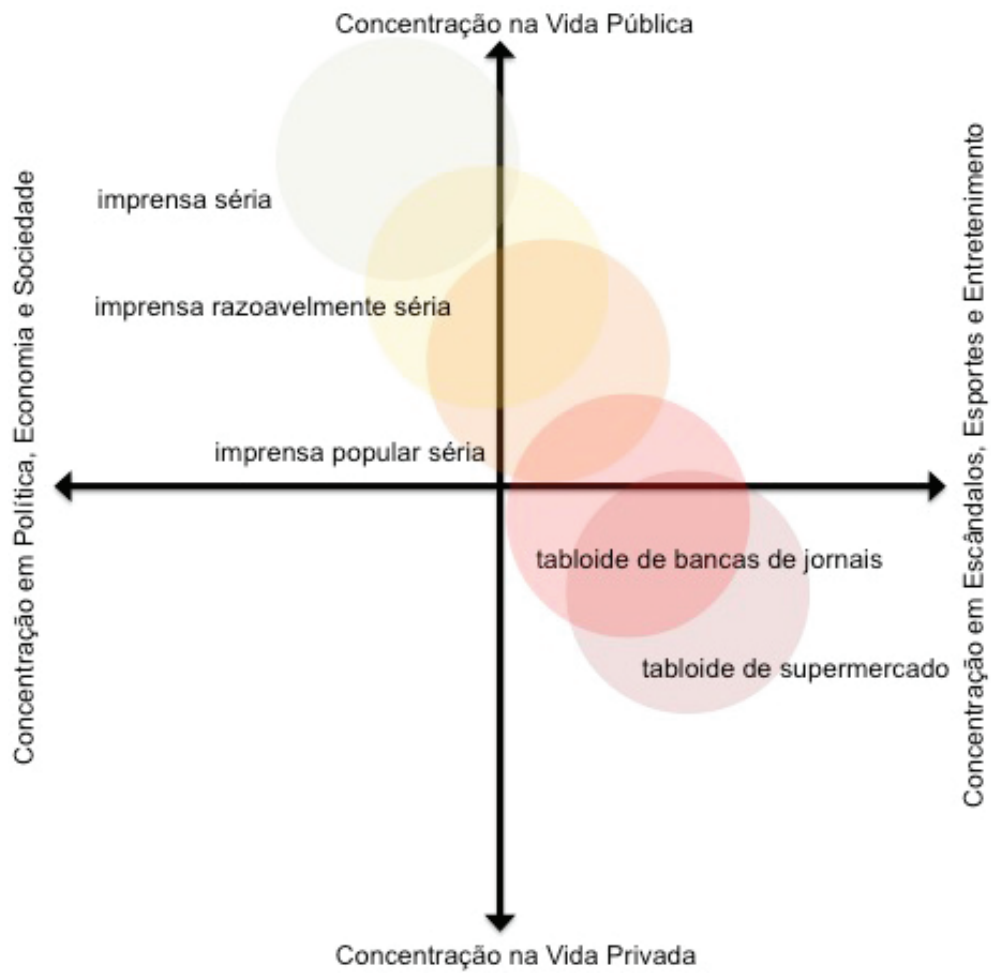

Fonte: Sparks (2000).

Elaboração própria.

Gripsrud (2000) é uma entre outras vozes a realçar as nuances do jornalismo popular, ao notar que o modelo antitético comumente adotado por pesquisadores de então não resume toda a complexidade do fenômeno. Para ele, é possível encontrarmos níveis intermediários entre a imprensa séria e a imprensa marrom, inclusive aquilo que ele denomina de uma imprensa "quality popular".

Os tabloides ainda não se acomodariam perfeitamente a quaisquer dos vértices sugeridos pelo modelo triangular de Schudson (1999), que dispõe,em suas extremidades, de uma mídia de mercado (market media), uma mídia partidária (advocacy media) e uma mídia curatorial (trustee media). A primeira ponta está alinhada com o 
modelo econômico sustentado pela publicidade e pela venda do produto jornalístico às audiências. Segundo Schudson (op. cit.), este modelo suplantou, na imprensa norte-americana (mas não em todo o mundo), aquele descrito pela segunda ponta, que aposta nas organizações partidárias como sustentáculos financeiros para os órgãos de imprensa. O terceiro vértice introduziria uma via jornalística independente, ancorada em um modelo produtivo que dissemina amplamente a subjetividade por meio de um jornalismo calcado em conteúdo curado por grupos de interesse e associações civis. $\mathrm{O}$ que se pode ressaltar é que, enquanto são claramente direcionados para fins comerciais, os tabloides também não têm nenhuma restrição aos modelos de atuação custeados por partidos ou grupos de interesse, e parecem explorar ao limite os níveis de subjetividade jornalística em seus padrões noticiosos.

Figura 2 - Tipologia de Gripsrud

\author{
jornalismo popular \\ jornalismo tabloide \\ jornalismo trash
}


O conteúdo dos tabloides é também objeto de Klein (2000), que procede uma análise de enquadramentos, partindo da premissa de que há dois modos de mensurar o processo de "tabloidização": o primeiro é observar a presença de temas políticos ou econômicos na pauta de diferentes meios de comunicação; o segundo é, em um mesmo determinado veículo, observar eventuais mudanças na cobertura política ao longo do tempo.

McLachlan e Golding (2000), então, propuseram diferentes eixos analíticos para a apreensão apurada do fenômeno, a saber: o alcance ou a variedade (range, no original), isto é, "a proeminência de diferentes áreas de cobertura" nas páginas do jornal; a forma ou o formato (form) expresso pela simplicidade da linguagem e do vocabulário utilizados; o endereçamento (mode of address), ou seja, o tratamento intimista e coloquial dado ao leitor; e a estrutura de mercado (market structure), que evidencia tensões da decisão em torno da cadeia produtiva e logística de distribuição. E, na sequência, outros pesquisadores, como Langer (2003), utilizaram-se de uma noção ampliada da categoria para definir processos de recrudescimento do sensacionalismo em meios como a televisão; ou, como Uribe e Gunter (2004), para alargar sua dimensão conceitual, aplicando-a a um cenário em que visualmente a imprensa aproximava-se de uma homogeneização em torno do formato tabloide, mas, no que tange a seu conteúdo, a diferença entre tabloides e quality papers seguia bem marcada.

$\mathrm{O}$ que fica patente em quaisquer dos autores dessa primeira leva de estudos em fins da década de 1990 é que, tanto na Europa quanto nos Estados Unidos, a assim chamada "tabloidização" era rotineiramente vista seja como uma ameaça, seja como uma condição revolucionária para as massas. Acadêmicos como o próprio Esser (1999) argumentavam que o fenômeno poderia ser compreendido sob duas perspectivas diversas, interpretações micro ou macro, cada qual com diferentes ênfases e alinhamentos. De um lado, teríamos, portanto, autores como Frank Esser, Colin Sparks e Ulrike Klein. De outro, Elizabeth Bird, John Fiske e Kevin Glynn.

O primeiro grupo, por exemplo, persegue um jornalismo de interesse público, e não hesitaria em classificar os tabloides como 
uma ameaça sensacionalista à imprensa de prestígio. Não é difícil assumir esse ponto de vista quando nos confrontamos com o cenário em que, diante da dura concorrência com os meios populares, os chamados quality papers precisam cumprir determinados quesitos para se reaproximarem da audiência. Esse panorama, contudo, como veremos, favorece uma leitura tipicamente centrada nos casos europeus e norte-americanos, largamente negativista em função do declínio da experiência dos meios tradicionais de imprensa. Pela defesa dos ideais do jornalismo de qualidade, tais autores são encarados por outros teóricos como integrantes de uma corrente elitista.

Em contrapartida, Bird e Fiske, entre outros, valorizam aquilo que identificam como o estilo irreverente e subversivo dos tabloides, que permite uma interpretação do jornalismo popular como desafiante do assim chamado "power bloc". Um pouco mais moderada que seu colega, Bird (2000, p. 214) admitiria que Sparks tem um ponto convincente em mãos quando afirma que pouca ou nenhuma evidência demonstra que os leitores efetivamente tomam para si o ponto de vista irônico que Fiske (2011) supõe, e que eles, em verdade, acabam por refletir,muitas vezes,uma visão reacionária dos fatos. Em todo caso, como diz a autora, há ainda uma quantidade limitada de pesquisas sobre essas audiências e seus comportamentos.

O que fica patente é o fato de que a preocupação maior dessa primeira corrente de estudos detém-se sobre o conteúdo dos jornais. Mesmo em uma análise eminentemente histórica do processo, como é o caso em Tulloch (2000), são as mudanças no conteúdo que se destacam. O que Tulloch descreve, por exemplo, é um movimento dialético, desenvolvido em fases, em que: a) os jornais partidários são confrontados inicialmente pela chamada penny press em meados do século XIX; b) durante o período que inaugura as "guerras de circulação" (circulation wars), o conflito entre veículos de distribuição em massa e órgãos elitizados ajudou a popularizar a imprensa; c) na sequência, o conflito entre jornais populares "virtuosos" e "nãovirtuosos" moldou o debate sobreojornalismoético;e,finalmente, d) a imprensa, já em fase de "tabloidização", enfrenta a concorrência cada vez mais acirrada da televisão. Contudo,sua periodização procura 
justamente tecer aproximações e distanciamentos entre os jornais hoje tidos como tabloidizados e o jornalismo popular-massivo introduzido pela penny press, que, ao contrário deles, privilegiava o factual, e foi, em grande medida, responsável por introduzir os princípios do paradigma norte-americano do jornalismo objetivo e imparcial. Para Tulloch (op. cit.), a "tabloidização" apresentaria, portanto, novos elementos a esse cenário se considerada em perspectiva histórica.

Conceituar o popular no que diz respeito à prática jornalística foi tarefa também prontamente aceita por Sparks (2000) e Durham (2008), que realçaram que o tabloide enfatiza narrativas pessoais, prioriza o impacto visual e enfoca a vida cotidiana. Diferentemente de Bird (2000) e Fiske (2011), estes pesquisadores, ainda que partindo de backgrounds acadêmicos distintos entre si, reconhecem nos tabloides um adversário à imprensa de qualidade. E é por isso, entre outros aspectos, que geralmente são confrontados com leituras culturalistas, como a de Glynn (2000, p. 9), segundo a qual "enquanto os gostos e práticas culturais de algumas pessoas ofenderem outras, não há dúvida de que estaremos diante da presença do elemento político". Glynn (op. cit.) argumenta que estamos vivenciando um período de emergência de uma cultura dos tabloides, que prioriza a saturação das imagens e das sensações sobre a realidade, torna instável a distinção entre público e privado e fragmenta os discursos. Fiske (2011), por sua vez, seguindo essa mesma linha, classifica o jornalismo tabloide como uma forma de "resistência", em uma apologia que Harrington (2008) diria não distinguir entre o "democrático" e o "demótico". $\mathrm{E}$, assim, o debate entre essas duas vertentes desenvolveu-se desde o princípio dos anos 1990 até meados da década seguinte.

A batalha entre as visões "populista" e "elitista" da relação entre jornalismo, cultura e sociedade sumariza a agenda acadêmica nas discussões sobre o fenômeno da "tabloidização". Desde então, a literatura tem tratado episodicamente de diferentes maneiras a questão e a partir de variados contextos. ${ }^{5}$ Predominantemente, tais estudos sobre

5 Ver Piontek (2011) sobre a Polônia; Mooney (2008) sobre a imprensa irlandesa; Harris (2006) sobre a imprensa moderna norte-americana; Lima (2009) sobre a relação entre os tabloides e o jornalismo on-line e outros. 
"tabloidização", que herdam a tradição do debate que se iniciou nos anos 1990, sugerem um contraste marcado entre a imprensa tabloide e a imprensa prestigiosa, fatalmente delimitado não pelo modelo econômico destes estudos, mas pelo conteúdo a que dão vazão. Os tabloides, neste sentido, são sempre contaminadores, para o bem ou para o mal, da imprensa tradicional, e jamais compartilham com ela exatamente os mesmos valores.

Além disso, em relação ao cenário vivenciado a partir da popularização da internet e de novos dispositivos tecnológicos, como tablets e smartphones, a competição pela sobrevivência dos grandes jornais acirrou-se de tal maneira em países como os Estados Unidos, a Grã-Bretanha e a Alemanha, que a "tabloidização" vem sendo encarada sob uma perspectiva ainda mais abrangente, segundo a qual o ambiente concorrencial com os novos meios tem favorecido a adoção de padrões de qualidade inferiores pelos grandes jornais, aproximando-os dos tabloides. Há quem (Johansson, 2007) sustente que as transformações na mídia em decorrência das mudanças tecnológicas recentes, "conquanto tenham afetado a apresentação das notícias, mudaram a própria natureza da atividade jornalística, sob formas que podem ser incorporadas tranquilamente às teorias sobre "tabloidização"' (op. cit.). Johansson recupera o argumento de Steven Barnett para lembrar que as novas tecnologias,

ao permitirem acesso instantâneo aos eventos e proverem uma proliferação de agentes noticiosos [...] colocam os jornalistas sob mais pressão para produzirem mais notícias em menos tempo, ocasionando uma abordagem comprometida em publicar a informação antes da checagem efetiva dos fatos, assim como maior depósito de confiança nos conteúdos gerados por relações públicas (Johansson, 2007).

Os tabloides seriam, nesse contexto, um tempero a mais no conflituoso panorama de competição enfrentado pelos grandes jornais (Wasserman, 2010; Conboy, 2006; Sparks, 2000). Quiçá um antiparadigma - ao menos no que tange ao ideal da produção jornalística. 
Enquanto, porém, a maior parte da literatura tem se concentrado em advertir sobre essa propalada crise e eventualmente associá-la a processos de "tabloidização", ainda é difícil encontrar um aporte acadêmico sistemático sobre temas que relacionam esta mesma crise aos efeitos experimentados em diferentes regiões do mundo. Como resultado, as análises reproduzem o modelo ocidental clássico (leia-se norte-americano e europeu) que ora demoniza ora santifica a "tabloidização" dos meios tradicionais, e compreendem a crise de modo absolutamente fatalista, enviesados pela perspectiva dos grandes jornais. Isso se deve, em alguma medida, ao fato de ambas as correntes interpretativas, a que suporta e a que combate o jornalismo tabloide, basearem-se em propostas que insistem em avaliar o conteúdo dos meios, em vez de considerar a forma como se apresenta a paisagem econômica.

Em contrapartida, pesquisas em alguns países em desenvolvimento têm sugerido que uma análise do comportamento dos mercados informacionais pode elucidar questões como a tendência positiva de crescimento na circulação e na conquista de novas audiências para a imprensa escrita, especialmente no segmento dos jornais, nessas regiões. Nesses casos, a abordagem econômica tem auxiliado a demonstrar com maior precisão o jogo de forças entre a mídia tradicional e outros contendores.

\section{O eixo Sul-Sul: a segunda geração de estudos sobre a "tabloidização" nos países em desenvolvimento}

George Brock (2013) cautelosamente adverte que, antes de propagarmos a ideia de que o fim da imprensa está próximo, em vista da crise a que assistimos, temos primeiro de considerar condições econômicas distintas em diferentes regiões. Como diz o autor, "desde há cinco anos até 2012, as circulações de jornais na Ásia têm aumentado 16\%, enquanto na Europa Ocidental e na América do Norte, elas caíram 17\%" (ibidem, p. 142). E acrescenta:

as circulações aumentaram na Índia, no Brasil, e na China. Na Índia, a alfabetização e o poder aquisitivo (jornais são baratos) 
estão entre os fatores dessa conta. Na China, autoridades exaltadas têm conduzido experimentos parcimoniosamente para permitir novas publicações que não estejam diretamente sob controle do Estado (Brock, 2013).

A esses países, soma-se o exemplo da África do Sul, que também tem conseguido enfrentar o cenário adverso apostando na popularização dos jornais. $\mathrm{O}$ que estes países têm em comum é a aposta evidente em um modelo de barateamento de sua carteira de produtos visando à massificação da audiência. Os tabloides claramente não se apresentam,então, como ameaças ao modelo jornalístico tradicional, senão como sua garantia de continuidade. Ao menos sob um ponto de vista econômico, a crise enfrentada pela grande imprensa contribui para uma mudança de expectativas. É sob essa perspectiva que surge a leva mais recente de contribuições sobre o tema da "tabloidização".

Autores como Herman Wasserman (2010), Maya Ranganathan e Usha M. Rodrigues (2010), Sevanti Ninan (2012) e George Ogola e Ylva Rodny-Gumede (2014) têm procurado apontar novas conformações na economia política do jornalismo, de forma a problematizar os modelos até então explorados pela primeira corrente de estudos capitaneada por pesquisadores como Sparks e Esser. Essa segunda geração de autores apresenta novas questões à medida que fatores como o incremento na alfabetização e no poder aquisitivo da população (conforme destacado por Brock anteriormente), o fim de guerras civis, de regimes de discriminação racial, o apaziguamento de tensões provocadas por questões de caráter religioso/fundamentalista e o avanço na popularização das novas tecnologias da comunicação (entre elas a internet), além, é claro, da adoção de estratégias de marketing cada vez mais agressivas para conquistar o leitor, têm contribuído para inverter a curva descendente dos indicadores de consumo para a imprensa escrita em países em desenvolvimento.

Ninan (2012, p. 15), por exemplo, ao investigar o caso da Índia, aponta que os jornais indianos, antes fomentadores do nacionalismo republicano, agora carregam a bandeira das mudanças materiais. A Pesquisa Nacional de Leitura (NRS, do inglês National Readership 
Survey) na Índia, no ano de 2005, apontava um total de 200 milhões de leitores para jornais e revistas, contra 131 milhões em 1999. ${ }^{6}$ São 98 milhões atualmente provenientes das zonas rurais do país, e a média de leitores por exemplar também vem caindo: de 22para cada cópia vendida, em 1997, para 8,4 auferidos em 2006 para a província de Uttaranchal. O Audit Bureau of Circulation, equivalente internacional ao Instituto Verificador de Comunicação(IVC) ${ }^{7}$ no Brasil, divulgou também em 2006 pesquisa que apontava que pelo menos 15 jornais em hindi e outros 11 em inglês tinham circulação superior a 100 mil exemplares. ${ }^{8}$ Nos últimos anos, um seleto grupo de dois ou três jornais indianos têm se alternado no posto de maior tiragem do planeta. O Times of India, maior veículo de língua inglesa, imprime mais de 4 milhões de exemplares ao dia. O popular Dainik Jagran não fica muito atrás, com 2,8 milhões de exemplares diários, mas um alcance de 17 milhões de leitores (Sood, 2009; Auletta, 2012). O modelo de negócios destes veículos investe massivamente em receita publicitária, chegando a obter índices superiores a 66\% (para o Dainik Jagran) e até 90\% (para o Times of India) do total de seu lucro, com anunciantes. Com esse cenário em vista, os periódicos podem circular com preços de capa inferiores a Rs. $10,{ }^{9}$ nos dias de semana, e Rs. 4 (o correspondente a R $\$ 0,15$ ), aos domingos, como é o caso do Dainik Jagran. O cenário também se tornou mais atrativo para o mercado de revistas a partir de 2002, quando o governo federal indiano ampliou o limite para investimento direto estrangeiro em mídia impressa, trazendo para o país franquias nacionais de revistas como Vogue, Marie Claire e outras (Rodrigues, 2010, p. 55).

Outra questão importante, como lembra Ninan (2012), é a expressiva quantidade de dialetos locais que recortam o país, dificultando uma comunicação que o atravesse plenamente. Além do hindi e do inglês, idiomas como telugu e punjabi são largamente adotados por

6 Os dados são apresentados por Ninan (2012, p. 15) a partir de matéria jornalística consultada no site Indian Television, disponível em: <http://www.indiantelevision.com/mam/headlines/y2k5/june/ junemam47.htm>.Acesso em: 18 fev. 2017.

7 Antigo Instituto Verificador de Circulação (IVC).

8 Ver Ninan (2012, p. 16).

9 Rs $=$ rúpias indianas. 
diferentes grupos. Essa condição levou o governo indiano não só a adotar um sistema que incorporasse uma certa permissividade à concessão de canais de radiodifusão, como também determinou a intensa regionalização dos veículos impressos. Deste modo, originou-se uma sólida base de periódicos regionais, incentivando a criação de conglomerados midiáticos de médio porte que figuram como atores políticos locais, na medida em que passam também a controlar emissoras de televisão e portais de conteúdo on-line.

A regionalização da cobertura da mídia impressa expandiu a esfera pública existente ao nível dos distritos, e então a reinventou quase que inconscientemente através da segmentação de edições. Isto trouxe consequências para a classe política e para a sociedade civil. Remodelou o senso de cidadania individual, adicionou uma nova dimensão à identidade do cidadão. E, ao mesmo tempo, por enfatizar a relação com a própria região, tornou o jornal relevante para uma base cada vez maior de leitores (Ninan, 2012, p. 26).

Já Rodrigues (2010, p. 54) cita os resultados de outro pesquisador, Vipul Mudgal, para lembrar de que as empresas distribuidoras dos maiores jornais desenvolveram-se a partir da expertise acumulada por empresas de distribuição de refrigerantes na Índia. Consistindo o negócio em uma complexa logística de entrega rápida e facilitada, tais empreendimentos revolucionaram a extensão da cobertura dos veículos, atraindo uma gama maior de anunciantes e revertendo um quadro que parecia negativo até então. Segundo a Indian Television, em pesquisa de $2009,48 \%$ da receita publicitária em mídia no país atende aos periódicos impressos, contra somente $37 \%$ que atendem à televisão. Para efeito de comparação, no Brasil, a televisão abocanha $66 \%$ do investimento publicitário, enquanto os jornais recebem uma parcela de apenas 10\%, segundo dados de 2013 do projeto Inter-Meios. ${ }^{10}$

10 O projeto foi descontinuado em 2015. 
Preços baixos, modelo de negócios baseado na publicidade paga, diversidade de oferta e ampla concorrência regional, fomentada, em particular, por veículos noticiosos de linguagem simples e caráter popular são fatores que ajudam a explicar, ao menos parcialmente, o sucesso do caso indiano. Entretanto, se analisados à parte dos aspectos socioeconômicos pelos quais passa a realidade local, eles não diferem fundamentalmente das questões elencadas por Esser em fins da década de 1990 e que o ajudaram a questionar o papel dos tabloides na Alemanha.

As mudanças socioeconômicas são também chave para a compreensão do estudo de Herman Wasserman (2010), que comenta sobre os efeitos da "tabloidização" na África do Sul, descrevendo o que ele vem a chamar uma "juniorização" das redações, assim como uma erosão da reportagem especial, e, ainda, um sobrepeso da visão comercial da imprensa. Essa última característica, inclusive, é considerada pelo pesquisador como a influência mais perniciosa dos tabloides sobre os quality papers, sendo tratada como um dos fatores da crise na imprensa tradicional. A esse respeito, Wasserman (op. cit.) ainda relaciona uma série de mudanças introduzidas com o avanço do processo de "tabloidização" na África do Sul, a primeira delas sendo o investimento massivo dos jornais mais prestigiosos em soluções tecnológicas, assim como em modelos de interatividade baseados em novas mídias. Os tabloides, como o autor argumenta, estão impondo mudanças aos meios tradicionais devido à competição entre eles. Entretanto,estas mudanças não dizem respeito exclusivamente ao formato de reportagem e diagramação, mas sobretudo ao tratamento íntimo legado aos leitores e ao modelo econômico que acompanha de perto as mudanças sociais no país.

Em primeiro lugar, o cenário promissor para os tabloides deve-se às dificuldades oriundas da concentração da propriedade dos meios em oligopólios, como os que Ogola e Rodny-Gumede (2014) descrevem para a mesma África do Sul (e também para o Quênia, na sequência).

Sob o apartheid, os jornais sul-africanos eram essencialmente controlados por quatro companhias, e pouco mudou. 
Hoje, duas dessas quatro companhias, dominam a cena dos jornais na África do Sul [...], controlando juntas aproximadamente dois terços do mercado [...].

A concentração de propriedade pós-apartheid tem se traduzido em saudáveis lucros aos seus empresários, mas o jornalismo tem sofrido bastante com tal cenário (Ogola e Rodny-Gumede, 2014, p. 230-231).

Ogola e Rodny-Gumede (2014) argumentam que, em vista dessa concentração, os grupos dominantes têm procurado reduzir o inchaço nas redações, além de apostarem na lógica cruel do modelo de syndication, adotado em várias outras partes do mundo. Neste modelo, uma equipe centralizadora produz material que é replicado para diferentes franquias de veículos locais, passando esta mesma equipe a compartilhar as responsabilidades editoriais de vários veículos.

Os tabloides, em contrapartida, têm apostado em uma lógica que se guia pela proximidade com o leitor, criando,em torno de si, como diz Wasserman (2010), aquilo que Benedict Anderson descreveria como uma "comunidade imaginada". O diagnóstico de Ninan (2012) sobre os jornais na Índia é relativamente semelhante. Para ele, como para Wasserman (2010, p. 86), os tabloides podem, sim, executar importante papel político no impulso à criação de uma espécie de esfera pública alternativa na África do Sul, resistindo à exclusão de determinados grupos do discurso mediado e provendo a esses leitores abertura para a participação em processos da política formal.

Os primeiros tabloides na África do Sul datam aproximadamente das décadas de 1930 e 1940 (Wasserman, 2010, p. 48), mas o impulso definitivo para o gênero é recente. Somadas às mudanças tecnológicas, às mudanças sociais e econômicas, às mudanças na propriedade dos meios e outras questões políticas advindas do fim do regime de apartheid, estão fixadas as bases para a crise no modelo da mídia mainstream no país. Segundo Wasserman (ibidem, p. 20), aparte os próprios tabloides, os jornais tradicionais sul-africanos têm amargado grandes perdas em sua circulação nos últimos anos. Mas, embora à primeira vista a visão do pesquisador pareça alinhar-se com 
as críticas ao jornalismo tabloide, sua argumentação sustenta que alguns pesquisadores acomodaram-se na clássica divisão que antepõe mídia tradicional e mídia alternativa como dois polos inconciliáveis, semenxergar queaimprensa tabloideconstitui, elamesma, umaterceira via que estressa essa dicotomia e assume características presentes em ambos os extremos sem, no entanto, configurar-se como qualquer um deles. $\mathrm{O}$ tabloide, como diz o autor, apresenta, ao mesmo tempo, uma visão lucrativa da imprensa, que se opõe à proposta da mídia alternativa, e se reconhece como produto eminentemente popular, em cujo sentido repousa a crítica à mídia tradicional de elite. Além disso, os jornais populares funcionam como um "espaço público emergente em que a cidadania é constantemente ensaiada e negociada" (ibidem, p. 47).

Entretanto, para além da concorrência econômica, os tabloides ainda enfrentam uma oposição forte da classe jornalística, na medida em que os profissionais que atuam nos veículos mais tradicionais têm dificuldade para enxergar os tabloides como prática integrada ao paradigma do jornalismo. Mesmo quando os aceitam, mais do que sugerir uma possível "abertura a diferentes estilos e abordagens", os grupos dominantes entre os jornalistas confinam os tabloides a um "gueto de jornalismo popular, não levando a sério o desafio que eles lhe impõem" (Wasserman, 2010, p. 62). Enquanto os tabloides forem percebidos desta forma, porém, a tendência é que ganhem ainda mais terreno entre as classes populares em si. Os prognósticos carecem de confirmação, mas o viés de pesquisa apontado por Wasserman (op. cit.) é claro no sentido de apostar em uma abordagem crítica da economia política.

Como outros autores dessa segunda corrente de pesquisa sobre a "tabloidização", Wasserman (2010) é partidário de uma vertente analítica que procura conciliar as perspectivas micro e macroscópicas. Tais autores apostam em estudos comparativos, como sinalizava Esser (1999), mas descartam uma visão a priori lamentadora sobre os efeitos desse processo. Além disso, e como resultado mais evidente de um cenário de multipolarização econômica, o debate acadêmico tem 
recrudescido em países em desenvolvimento, originando um diálogo particular entre essas realidades e suas particularidades.

Em vez de se enxergar a mídia local a partir de exemplos particulares de um projeto globalmente dominante [...], uma abordagem translocal encorajaria comparações entre diferentes meios"locais", a partirde estudosSul-Sul,com comparações entre tabloides em diferentes partes do mundo em desenvolvimento ou em diferentes países africanos (Wasserman, 2010, p. 55).

É neste sentido que os estudos sobre o jornalismo popular no Brasil carecem de maior ímpeto investigativo. Há lacunas claras, como veremos a seguir, na compreensão sobre a organização econômica dos conglomerados e o espaço político que ocupam hoje esses veículos.

\section{O mercado brasileiro de jornais populares}

O Brasil é pródigo em incorporar ao jornalismo formas alternativas que misturam humor e subjetividade. Desde pelo menos meados da década de 1950, reconhece-se, no país, um gênero de jornalismo popular perpassado pelo vetor do paralelismo político em jornais como O Dia, Diário de Notícias e O Povo. Ainda antes, pode-se argumentar, revistas ilustradas faziam uma mescla entre a imprensa tabloide e os panfletos partidários. Mas, sobretudo a partir do processo de redemocratização, e com o rearranjo de alguns grupos de mídia nas décadas de 1980 e 1990, os tabloides ganharam fôlego em diversas cidades brasileiras. Muitas vezes ocupando o formato broadsheet típico da imprensa tradicional, em outras utilizando o formato intermediário berliner, e somente em determinados casos adotando de fato o tabloide,esses veículos despontaram como jornais largamente acessíveis à população e têm alcançado bons índices de venda nos anos recentes, a ponto de muitos deles figurarem nas relações de jornais de maior circulação do país na última meia década.

Tome-se o exemplo do mineiro Super Notícia. O preço (R\$ 0,25) e a linguagem popular alçaram o veículo à condição de campeão de 
circulação no país, segundo o IVC. ${ }^{11}$ Mas o jornal é, em realidade, herdeiro do tradicional grupo O Tempo. No Brasil, diferentemente de outros países, as fronteiras entre o jornalismo tabloide e o jornalismo de prestígio têm um componente político-econômico que dificulta sua apreensão. À medida que os jornais de cunho popular são patrocinados pelos mesmos conglomerados midiáticos que mantêm veículos afinados ao mainstream, o cenário tende a uma situação em que a concorrência é substituída por uma espécie de complementaridade.

A bem da verdade, na África do Sul, Wasserman (2010) descreve algo parecido. Nas palavras do pesquisador, contudo, os tabloides são alavancados por outros produtos de um mesmo grupo de mídia, já que teriam dificuldade para cobrir custos diante do ínfimo preço final.

O debate sobre tabloides e a mídia mainstream deve conter um foco político-econômico crítico. Todos os tabloides sul-africanos pertencem a conglomerados comerciais, então poderia ser esperado que se auferissem mais vantagens para os interesses dos empresários do que para a agenda de deliberação pública. $\mathrm{O}$ apoio dos conglomerados aos tabloides é também importante por sua alta popularidade. $\mathrm{O}$ fato de que tabloides podem ser vendidos [...] a um preço barato porque são transsubsidiados por outros produtos no mesmo grupo de mídia deveria também ser levado em consideração quando se discute a sua popularidade. Os leitores podem comprá-los em parte por conta do preço barato, e não apenas porque provêm o conteúdo desejado. Inferências excessivamente simplistas sobre conteúdo e preferencias da audiência devem, portanto, ser evitadas (Wasserman, 2010, p. 78-79).

11 A afirmação está baseada em consultas realizadas ao banco privado do instituto, cuja cortesia agradecemos. A metodologia do IVC foi alterada a partir de meados de 2015, quando o órgão passou a somar as circulações impressa e digital dos veículos, levando os grandes jornais, como Folha de S. Paulo e Estadão, a reassumirem as principais posições no ranking. 
Diferentemente do que ocorre em outros países, no Brasil, os tabloides abastecem o mercado com uma solução complementar,embora razoavelmente autônoma, que alia o potencial de captação de publicidade e a receita gerada por meio do modelo de assinaturas de grandes jornais ao sucesso absoluto no segmento de venda avulsa dos primeiros. ${ }^{12}$ Assim, como já tratamos em outros momentos, ${ }^{13}$ jornais populares têm servido à estratégia de diversificação da carteira de produtos de conglomerados midiáticos, de forma a compor binômios ou mesmo trinômios comunicacionais, em que se somam a jornais de prestígio para alcançar um modelo de maior viabilidade econômica para a sustentabilidade empresarial do negócio como um todo. Se bem é verdade que o faturamento dos jornais populares está ainda distante da margem atingida pelos veículos tradicionais (ver tabela 2), tal estratégia de diversificação tem contribuído tanto para ampliar a margem de negociação com anunciantes quanto para alcançar novos públicos, considerando-se em especial a propensão dos veículos mais tradicionais a voltarem-se cada vez mais para segmentos específicos da elite. Assim, ao veículo de "alta estirpe" somam-se produtos cuja marca é menos consistente (no sentido de se tornar um título de referência nacional e de credibilidade junto ao mercado investidor), mas com uma base de leitores mais abrangente, e, portanto, não apenas os grupos de mídia penetram uma nova camada do mercado de discursos públicos com esses novos produtos (Chagas, 2014a; 2014 b), como se apresentam mais atrativos aos investidores. Percebendo essa potencialidade, grupos como Infoglobo e O Dia oferecem, inclusive, a possibilidade de preços promocionais para a publicidade casada. ${ }^{14} \mathrm{E}$, desta forma, o investidor preserva ativos como credibilidade e segurança de seu investimento em uma marca sólida e amplia a abrangência do conteúdo publicitário às camadas populares.

\footnotetext{
12 A pesquisa continuada pretende ainda investigar a hipótese de que o ideário político-panfletário dos grandes conglomerados é diluído, mas não obliterado do jornalismo tabloide, o que contribui para a compreensão de que, além de estender economicamente o alcance desses empreendimentos, os veículos populares servem também para a ampliação da abrangência ideológica desses grupos.

13 Ver Chagas(2014) e Lattman-Weltman eChagas (2013; 2016).

14 Os próprios classificados dos jornais O Globo e Extra foram unificados pelo menos desde maio de 2012, transformando-se em "Classificados do Rio".
} 
Tal estratégia aponta para um caminho levemente distinto do identificado por outros autores em seus respectivos contextos, e, por essa razão, apresenta novos desafios e possibilidades. Um desses desafios é a ocorrência do fenômeno que temos classificado (Lattman-Weltman e Chagas, 2013; Chagas, 2013) como "fogo amigo", isto é, a concorrência de canibalização da audiência em veículos de perfil de consumo complementar pertencentes a uma mesma empresa jornalística, como parece ser o caso entre os jornais O Dia e Meia Hora, no Rio de Janeiro, em que o primeiro tem amargado seguidas quedas de circulação após a entrada do último no mercado. Entretanto, deve-se levar em consideração que a existência dos tabloides, de certa forma, permite ou ao menos contribui para a manutenção, e mesmo o amadurecimento, do modelo jornalístico que aposta na "qualidade" do produto.

Em vez, portanto, de encararmos uma crescente contaminação dos quality papers pela agenda dos tabloides, o que temos visto é um intenso desenvolvimento de um novo mercado editorial a partir da entrada dos veículos populares como solução econômica alternativa ao modelo de negócios dos tradicionais grupos de mídia. Em paralelo, os grandes jornais têm apostado cada vez mais em um segmento de nicho, dito "formador de opinião", que lhes oferece a possibilidade inclusive de tomarem partido nas questões nacionais com mais clareza (Lattman-Weltman e Chagas,2013). O principal resultado desse reposicionamento econômico está refletido nos indicadores sobre a leitura de jornais da Pesquisa Brasileira de Mídia 2014, divulgada pela Secom (Brasil, 2014), que aponta melhor desempenho médio na pesquisa espontânea sobre os jornais mais lidos de segunda a sexta-feira para os formatos populares. Em outras palavras: os leitores lembram-se com mais imediatez, quando perguntados que jornais leem com mais frequência, de títulos populares do que daqueles tradicionais, no geral (ver tabela 1).

Assim, inspirados em parte nas ideias de Uribe e Gunter (2004), buscamos, com este trabalho, avaliar o estado de um eventual processo de "tabloidização" nos mercados brasileiros, recorrendo também - a contragosto de Esser (1999) - a indicadores de desempenho dos 
próprios tabloides. Para apresentarmos essas questões, procuramos montar um quadro da evolução da penetração dos jornais impressos na sociedade brasileira e dos hábitos de consumo de mídia da população nos últimos anos, ancorados em dados do anuário Mídia Dados 2013, do Grupo de Mídia São Paulo (2013), e da Pesquisa Brasileira de Mídia 2014, da Secom (Brasil, 2014), além de outras bases. Os indicadores apontados nas pesquisas são significativos, na medida em que, especialmente a segunda, aponta um declínio evidente do impacto do setor de impressos na experiência social cotidiana do brasileiro médio: apenas 25\% dos respondentes afirmam ler jornais habitualmente. Em contrapartida, os mesmos dados apontam que, entre os seus consumidores, o tempo médio de leitura de um jornal pode variar de 45 minutos, entre os habitantes do Tocantins, a 2horas e 12 minutos, entre os de Goiás. O abismo entre os 75\% de consumidores que não leem jornal e o leitor que gasta 2 horas e 12 minutos de seu dia folheando um exemplar é, em parte, o que justifica o investimento das empresas em produtos com perfil distinto.

Nos últimos anos, como comprovam dados do IVC, ${ }^{15}$ os jornais populares têm alcançado índices de circulação surpreendentes, chegando, inclusive, a superar veículos bastante tradicionais. É o caso novamente do mineiro Super Notícia, que tem alternado há pelo menos quatro anos a liderança do ranking com a Folha de S. Paulo. As mudanças no setor, em parte decorrentes da reviravolta econômica impulsionada pelo acesso às novas tecnologias da comunicação, em especial a internet e as mídias digitais, têm se refletido inclusive em alterações no regime de auditoria do setor. Nos últimos anos, o IVC tem procurado incorporar às suas métricas indicadores que permitam mensurar com maior eficácia a circulação de edições digitais dos jornais. Os próprios grandes jornais que mantêm portais on-line, com sua adesão ao sistema de paywall poroso - que permite que usuários acessem uma quantidade limitada de conteúdos por mês, para depois serem convidados a assinar o jornal -, têm investido de modo cada vez mais decisivo na fidelização do consumidor,

15 Ver nota 11. 
deixando paulatinamente o mercado da venda direta aberto aos gêneros populares.

De posse dessas considerações preliminares, procuramos arregimentar dados acerca do desempenho desses jornais populares no mercado brasileiro. Para efeito de demonstração, optamos por trabalhar com um corpus de oito jornais. Este corpus reflete uma tentativa de equilibrar os dois diferentes perfis de consumo: os quality papers (Folha de S. Paulo, O Estado de S. Paulo,O Globoe Zero Hora) e os jornais tabloides (Meia Hora, Super Notícia, Extra e O Dia). ${ }^{16}$ Os títulos foram extraídos da relação de 20 maiores circulações médias do país nos últimos cinco anos, com base em dados do IVC, ${ }^{17}$ e contrastados com os demais indicadores disponíveis, de forma que o corpus final melhor se adequasse aos dados levantados por essa etapa de pesquisa. ${ }^{18}$ Desta forma, pudemos também agrupar os resultados para torná-los mais elucidativos.

Chama a atenção a comparação entre os dados da Secom (2014) e do portal Meio \& Mensagem (2014). O primeiro órgão apresenta, como apontamos, levantamento sobre os jornais mais lidos, indicados espontaneamente pelos consumidores. A pesquisa aplicou um formulário de 75 perguntas a uma amostra de 18.312 brasileiros em 848 municípios em 2013.Já Meio \& Mensagem é responsável pela divulgação do Índice de Prestígio das Marcas (IPM). O índice, elaborado e aprimorado ao longo dos últimos 13anos, consolida entrevistas fechadas com diferentes atores do mercado, entre eles investidores do mercado publicitário, donos de agência etc. No último ano, foram cerca de 800 entrevistados pela consultoria Troiano Branding. O IPM baseia-se em um conjunto de cinco variáveis, assim denominadas:

16 Vale levar em consideração algumas peculiaridades a respeito dos veículos elencados. Sabemos, por exemplo, que os três primeiros quality papers selecionados possuem abrangência nacional muito mais evidente que o jornal Zero Hora, de atuação destacadamente regional. Entre os tabloides, Meia Hora e Super Notícia são dirigidos a um público claramente mais popular do que Extra e 0 Dia (ainda que dados da Secom possam questionar essa perspectiva, no que tange às faixas de renda dos consumidores pesquisados). Tais diferenças de perfil na amostra selecionada, contudo, não invalidam a hipótese que tratamos neste artigo.

17 Ver nota 11

18 Jornais, por exemplo, como O Estado de Minas, Daqui (GO), os gratuitos Destak e Metro, e outros mais, foram deixados de fora em virtude de não dispormos de dados suficientes para sua avaliação. Esses veículos, no entanto, podem ser incorporados em etapas futuras da pesquisa. 
credibilidade, ética, conteúdo editorial, inovação e eficácia. As variáveis têm diferentes pesos para cada segmento da mídia, e, para o jornalismo impresso, os três primeiros índices são os que detêm maior peso na média final. $\mathrm{O}$ índice, no entanto, não fornece dados completos sobre o panorama dos jornais impressos no país, uma vez que os veículos que não alcançam a linha de corte ou que não são citados espontaneamente pela maioria dos entrevistados, são automaticamente eliminados. Consideramos, portanto, para fins de análise, somente os dados dos veículos disponíveis, tanto na Pesquisa Brasileira de Mídia quanto no IPM, conforme tabela 1 e gráfico 1.

Tabela 1 - Comparativo de índices Secom vs. IPM

\begin{tabular}{c|c|c}
\hline Jornais & IPM & Secom \\
\hline O Estado de S. Paulo & 68,5 & $1,3 \%$ \\
\hline Folha de S. Paulo & 63,5 & $2,1 \%$ \\
\hline O Globo & 47,2 & $3,6 \%$ \\
\hline Zero Hora & 34,8 & $3,3 \%$ \\
\hline O Dia & $\mathrm{N} / \mathrm{D}$ & $2,3 \%$ \\
\hline Extra & 14,9 & $7,1 \%$ \\
\hline Meia Hora & $\mathrm{N} / \mathrm{D}$ & $4,5 \%$ \\
\hline Super Notícia & $\mathrm{N} / \mathrm{D}$ & $5,5 \%$ \\
\hline
\end{tabular}

Fonte: Dados do IPM obtidos de Meio \& Mensagem (2014). Os demais, obtidos de Brasil (2014).

Obs.: Unidades: N/A para a segunda coluna; percentual sobre a amostra pesquisada para a terceira. 
Gráfico 1 - Comparativo de índices Secom vs. IPM

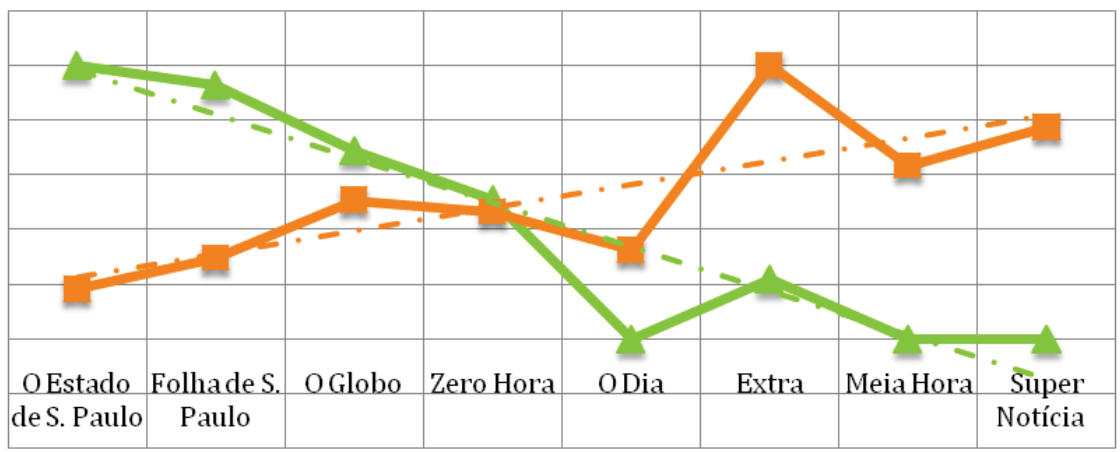

- IPM $\rightarrow-$ Secom

Elaboração própria.

O que a discrepância entre os dois índices parece ressaltar é a distância entre os usos e investimentos do mercado e a apropriação do consumidor. Assim, os veículos mais à esquerda do gráfico 1 assumem a preponderância quando os entrevistados pertencem a um nicho de investidores e profissionais de mídia. O desempenho desses jornais não é o mesmo com relação à curva que representa os dados da segunda pesquisa, realizada com o consumidor em geral. Com os jornais à direita do gráfico 1 , acontece o inverso: o mercado publicitário praticamente os desconsidera (com exceção do jornal Extra, que ao menos aparece na pesquisa de Meio \& Mensagem, ainda que mal posicionado), mas os leitores os elencam entre os jornais mais lidos do país. As curvas de tendência linear apontam para uma convergência bastante curiosa em performances como a do jornal Zero Hora. Em princípio, tal resultado poderia significar uma faixa intermediária entre os quality papers e os veículos mais populares, mas a hipótese precisaria ser testada com dados de outros veículos.

Com relação aos investimentos publicitários, novamente o que notamos é uma concentração intensa de verbas em veículos de maior prestígio junto aos investidores. Um tabloide como Super Notícia, por exemplo, que não possui sistema de assinaturas, confia praticamente apenas na soma entre ganhos com publicidade e receita obtida 
diretamente da venda avulsa do jornal. ${ }^{19}$ Grosso modo, estamos falando de um valor que gira em torno de R\$198.631.067,70/ano, a que chegamos somando-se o faturamento publicitário expresso na tabela 2 ao valor final obtido da venda direta do jornal, de apenas R\$ $74.717,65 .^{20}$ É difícil, com os dados de que dispomos, não supor que o grupo $O$ Tempo, mantenedor do tabloide, não tenha alternativas ao modelo econômico que inclui venda direta e publicidade apenas. Isso não significa, porém, uma ressalva à sustentabilidade econômica de Super Notícia. A pesquisadora Kátia Maria Belisário (2014) cita uma dessas estratégias: os jornais Super Notícia e O Tempo compartilham, segundo ela, a mesma redação, tendo adotado o modelo de syndication criticado por Ogola e Rodny-Gumede (2014).

De toda forma, o jornal é instrumento fundamental para que o conglomerado afirme sua preponderância no estado mineiro, diante da concorrência do grupo Diários Associados, que detém, entre outros, o quality $\mathrm{O}$ Estado de Minas e o tabloide Aqui BH. Ainda assim, salta aos olhos, ao observarmos a figura 2, que a concentração de investimentos do mercado anunciante sobre jornais de prestígio distorce, em certo sentido, o modelo tradicional da imprensa norte-americana, calcada na compensação entre preço final do produto e captação de publicidade como valores inversamente proporcionais, isto é, quanto menor o preço (ver tabela 3),maior a necessidade de incorporar investimentos do setor publicitário para equilibrar as contas do jornal.

Ao menos no Brasil, portanto, o modelo da penny press é amplamente ineficaz como explicação para dar conta da economia política dos jornais impressos, pois a concentração da receita de investidores sobre os títulos de maior prestígio mina a existência sustentável de

19 Evidentemente, não estamos desconsiderando aqui o fato de que muitos desses jornais populares e ultrapopulares, Super Notícia inclusive, lançam mão de diferentes estratégias mercadológicas para conquistar maior parcela da audiência. Entre estas estratégias, uma das mais difundidas baseia-se na divulgação de promoções a partir de cupons impressos e na distribuição de itens colecionáveis junto às edições diárias. Em todos esses casos, porém, trata-se de um esforço para ampliação da venda avulsa do jornal.

20 A venda direta foi obtida a partir da multiplicação da quantidade de exemplares distribuídos em média pelo jornal nos últimos cinco anos $(298.870,6)$ pelo valor do seu preço de capa $(R \$ 0,25)$. Naturalmente, o cálculo desconsidera outras possíveis fontes de renda ao jornal. Trata-se apenas de uma aproximação. 
tabloides independentes dos grandes conglomerados midiáticos. As curvas de tendência no gráfico 2 têm ocorrência absolutamente paralela, tendendo positivamente para os jornais dispostos à esquerda - o que demonstra não apenas a oscilação em uníssono dessas duas variáveis e, consequentemente, um padrão de mercado que certamente explica o cálculo para a precificação dos veículos, mas também que os tabloides só podem ter atuação econômica relevante como integrantes de um modelo complementar. Isto, porém, não diminui o capital político dos jornais populares ante os jornais de prestígio, muito pelo contrário: são os tabloides, de acordo com nossa visão, os responsáveis por estender o alcance potencial dos grupos de mídia que compõem.

Tabela 2 - Investimentos publicitários

\begin{tabular}{c|c|c}
\hline 0 Estado de S. Paulo & $3.109 .616,58$ & $1,07 \%$ \\
\hline Folha de S. Paulo & $3.303 .514,37$ & $1,14 \%$ \\
\hline 0 Globo & $1.336 .043,89$ & $0,46 \%$ \\
\hline Zero Hora & $311.028,23$ & $0,11 \%$ \\
\hline 0 Dia & $333.724,53$ & $0,12 \%$ \\
\hline Extra & $767.291,37$ & $0,27 \%$ \\
\hline Meia Hora & $274,153,86$ & $0,09 \%$ \\
\hline Super Notícia & $198.556,35$ & $0,06 \%$ \\
\hline Total & $289.248 .811,3$ & $100 \%$ \\
\hline
\end{tabular}

Fonte: Dados de faturamento de cada veículo cedidos pelo lbope. Total de investimentos no setor de jornais impressos consolidado pelo projeto Inter-Meios.

Obs.: Unidades: milhares de reais ( $R \$$ mil) para a segunda coluna.

Tabela 3 - Preço de capa

\begin{tabular}{c|c}
\hline 0 Estado de S. Paulo & $R \$ 3,00$ \\
\hline Folha de S. Paulo & $R \$ 3,00$ \\
\hline 0 Globo & $R \$ 2,00$ \\
\hline Zero Hora & $R \$ 2,50$ \\
\hline 0 Dia & $R \$ 1,20$ \\
\hline Extra & $R \$ 1,10$ \\
\hline Meia Hora & $R \$ 0,70$ \\
\hline Super Notícia & $R \$ 0,25$ \\
\hline
\end{tabular}

Elaboração própria. 
Gráfico 2 - Investimentos publicitários vs. preço de capa

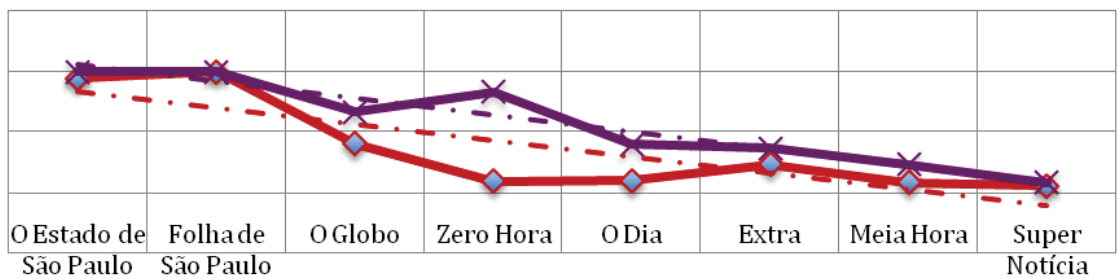

$\leadsto$ faturamento publicitário $\quad *$ preço de capa

Elaboração própria.

Segundo novamente a pesquisa da Secom, o espaço médio ocupado pelo noticiário de política nos hábitos do consumidor brasileiro é de apenas 7\% em relação aos demais cadernos do jornal (Brasil, 2014) ${ }^{21}$ Este espaço varia de 6 (mulheres) a 8 (homens) pontos percentuais (p.p.) de acordo com o gênero, e de 3 (menos de um salário mínimo) a 11 (mais de cinco salários mínimos) p.p. de acordo com a renda familiar. Contudo,em nenhum corte supera o patamar dos 12\% (entrevistados com Ensino Superior). Entretanto, temas relacionados às editorias de "cidades" (33\% na média nacional), "esportes" (25\%), "notícias do Brasil" (21\%), "notícias policiais" (16\%) e "celebridades/fofocas/novelas" (16\%) são os campeões entre os leitores. Política, juntamente a economia e cultura, amarga os piores índices. O panorama ajuda a compor o complexo quadro sobre o caráter popular dos jornais mais citados entre os leitores, segundo a Secom. E, em paralelo, coloca uma importante discussão sobre o que podemos entender por jornalismo tabloide no Brasil.

É bem verdade que raramente nos referimos, seja no ambiente acadêmico, seja fora dele, a "tabloides" na imprensa nacional. O termo comumentedifundidotrataessetipodeveículocomo "jornalpopular". ${ }^{22}$ Assim é que a pesquisadora Kátia Belisário (2014, p. 70) a eles se

21 A pergunta aplicada aos entrevistados pela pesquisa foi a seguinte: "que parte ou assunto do jornal impresso o(a) sr(a). costuma ler mais? (Espontânea $-1^{\circ}+2^{\circ}$ lugares)".

22 Normalmente, no Brasil, o termo "tabloide" é utilizado menos como referência a um gênero jornalístico e mais ao formato específico. A recente adoção de alguns jornais de prestígio ao papel de tamanho tabloide pode ajudar a trazer para o debate público a ressignificação dessa categoria. 
refere em sua tese de doutorado, pontuando que, "de forma geral, [esses jornais] são estigmatizados como espaço de alienação, que não permitem a tomada de consciência e a luta política”. Vemos aí, mais uma vez, a mesma questão que evoca Wasserman (2010) ao sugerir que os tabloides ocupam uma lacuna intermediária entre a mídia alternativa e a mídia tradicional. No entanto, uma questão precede esse debate: o que podemos conceber como um jornalismo popular?

Segundo Hall (2011), em seus clássicos apontamentos sobre cultura popular, há uma oscilação dialética comum entre dois polos (de "contenção" e "resistência") no que tange à interpretação da noção mesma de popular. De um lado, ela se reveste de uma interpretação que se alia à transformação cultural que rompe com a ameaça da hegemonia;de outro, ela traduz a ideia do massivo como meio de alienação. Popular, enfim, pode tanto reforçar o que é feito "pelo povo" quanto o que é difundido "para o povo". Mas Hall (op. cit.) admite também algumas nuances a essas leituras que acrescentam novos nós, quando trata da imprensa popular. Diz ele:

podemos perceber como a imprensa liberal da classe média da metade do século dezenove foi construída às custas da efetiva destruição e marginalização da imprensa local radical da classe trabalhadora. Mas, além desse processo, algo qualitativamente novo ocorre mais para o final do século dezenove e o começo do século vinte nessa área: a efetiva inserção em massa de uma audiência desenvolvida e madura da classe trabalhadora num novo tipo de imprensa comercial popular [...]; organizada pelo capital "para" as classes trabalhadoras; contudo, com raízes profundas e influentes na cultura e na linguagem do "João Ninguém", "da gente"; com poder suficiente para representar para si mesma esta classe da forma mais tradicionalista (Hall, 2011, p. 235).

Essa nova "modalidade" surge, então, para reconfigurar a oposição dialética entre popular e massivo, pois incorpora elementos de ambos os extremos. Neste sentido, na seara da imprensa popular, os tabloides 
tencionam a distância entre o mais "conhecido" e o mais "consumido", aproximando ambas as dimensões. Ao fazer isso, colocam em xeque não somente a imprensa alternativa/revolucionária, mas também e principalmente os grandes jornais de prestígio, cujo lugar ocupado é revisto.

Dados como os apresentados pelo IPM (Meio \& Mensagem, 2014) e pela pesquisa da Secom (Brasil, 2014) abrem uma discussão sobre a definição do popular como mais "consumido/conhecido" ou mais "lembrado/reconhecido". Afinal, a pesquisa do governo federal não trata do âmbito meritocrático da imprensa dita de qualidade;apenas questiona os entrevistados sobre que jornal consomem com maior regularidade. Diante disso, é inegável que uma instância de "popularidade" é perdida no processo: aquela mesma que procura cobrir a pesquisa sobre o prestígio das marcas. Muito embora essa percepção não compactue inteiramente com o viés apontado por Hall (2011) e esteja, inclusive, em mais de um sentido, em oposição a ele, é importante notarmos que a imprensa de prestígio é também popular, na medida em que não apenas reflete um caráter massivo da experiência de consumo dos meios de comunicação modernos, mas sobretudo é "prestigiosa", e, desse modo, exerce sobre as classes populares uma popularidade advinda de seu reconhecimento pela elite. Fosse outra a pergunta proferida pelos entrevistadores no levantamento do governo federal, o resultado poderia apontar para um predomínio dos grandes jornais como os mais citados na pesquisa espontânea. Afinal, é comum que, inclusive pesquisadores, atenham-se a jornais como Folha de S. Paulo, O Estado de S. Paulo e O Globo comode abrangência nacional, quando, em realidade, o alcance deles é bem mais restrito do que imaginamos. Podemos facilmente demonstrar essa questão observando mais uma vez os dados sobre a proporção da amostra de entrevistados na pesquisa da Secom que citou os jornais integrantes de nosso corpus como os mais lidos. Se a amostra é efetivamente representativa da população brasileira como a pesquisa sugere, uma operação simples de abstração a partir de seus números nos permitiria chegar a um índice interessante: multiplicando-se o percentual obtido na menção a cada veículo pelo total da população 
brasileira em 2013, mapeado pelo recenseamento do Instituto Brasileiro de Geografia e Estatística (IBGE) (201.032.714 habitantes), ${ }^{23}$ e dividindo-se o resultado pela quantidade média de exemplares de um determinado veículo em circulação, teremos um valor que procura medir a proporção entre leitores e exemplares. $\mathrm{O}$ resultado, expresso na tabela $5,{ }^{24}$ é caracterizado por uma razão de habitantes por exemplares, e procura indicar, mediante aproximação matemática, quantos entre os leitores presumidos pela pesquisa têm efetivamente acesso a um exemplar do jornal. A métrica não se equipara à quantidade de leitores por que um determinado exemplar do jornal circula após a venda, como buscam fazer indicadores de audiência baseados em metodologias internacionais, como o readers per copy. Tampouco se resume à apreensão do número de pessoas que recebem uma cópia do jornal (net paid circulation), pois esse índice é a própria circulação do jornal, conforme relacionamos a seguir (ver tabela 4). Seu objetivo é apenas propor um exercício que busque refletir sobre a quantidade de exemplares posta em circulação de acordo com a demanda de consumo. Isto é, se há um percentual tal de pessoas que consomem aquele veículo regularmente, mas há uma quantidade limitada de exemplares à disposição;quantos leitores, entre os que demandam pela leitura de um dado título,aglutinam-se em torno de um exemplar específico? A resposta permite-nos identificar que veículos têm demanda mais concentrada, índice que optamos por denominar aqui,portanto,de "demanda potencial", e é expresso em habitantes por exemplar $(\mathrm{h} / \mathrm{e})$.

23 Ver Abdala e Giraldi (2013).

24 Naturalmente, trata-se, mais uma vez, de uma aproximação sem valor estatístico, apenas como efeito de exercício matemático, para a apreensão da natureza econômica dos meios. 
Tabela 4 - Circulação

\begin{tabular}{c|c}
\hline & Circulação \\
\hline 0 Estado de S. Paulo & $235.963,4$ \\
\hline Folha de S. Paulo & $296.045,2$ \\
\hline O Globo & $263.736,6$ \\
\hline Zero Hora & $185.220,0$ \\
\hline O Dia & $57.803,6$ \\
\hline Extra & $238.051,2$ \\
\hline Meia Hora & $155.155,8$ \\
\hline Super Notícia & $298.870,6$ \\
\hline
\end{tabular}

Fonte: Dados cedidos pelo IVC.

Obs.: Unidades: média de exemplares nos últimos cinco anos.

Tabela 5 - Demanda potencial

\begin{tabular}{c|c|c|c}
\hline & Secom & Base de leitores & Demanda potencial \\
\hline 0 Estado de S. Paulo & $1,3 \%$ & $2.613 .425,28$ & $11,07 \mathrm{~h} / \mathrm{e}$ \\
\hline Folha de S. Paulo & $2,1 \%$ & $4.221 .686,99$ & 14,26 \\
\hline O Globo & $3,6 \%$ & $7.237 .177,70$ & 27,44 \\
\hline Zero Hora & $3,3 \%$ & $6.634 .079,56$ & 35,81 \\
\hline O Dia & $2,3 \%$ & $4.623 .752,42$ & 79,99 \\
\hline Extra & $7,1 \%$ & $14.273 .322,69$ & 59,95 \\
\hline Meia Hora & $4,5 \%$ & $9.046 .472,13$ & 58,30 \\
\hline Super Notícia & $5,5 \%$ & $11.056 .799,27$ & 36,99 \\
\hline
\end{tabular}

Fonte: Dados de Brasil (2014) contrastados com IBGE. Obs.: Unidades: leitores e habitantes por exemplares.

Pelos resultados encontrados, é possível reconhecer novamente uma linha razoavelmente bem marcada entre tabloides e quality papers, à medida que os últimos têm demanda menos concentrada. $\mathrm{O}$ mesmo acontece se considerarmos outra métrica, que aqui 
denominamos de "concentração de investimentos", e é expressa pela razão entre o faturamento publicitário de cada veículo e esta mesma média de circulação que consideramos no exemplo anterior. O resultado é apontado na tabela 6. Com exceção de $O$ Dia, cujas quedas sucessivas em sua circulação nos últimos anos parecem não impactar substancialmente a captação de recursos de anunciantes, todos os demais tabloides apresentam índices de concentração bastante abaixo dos chamados grandes jornais. Estes, por sua vez, com exceção de Zero Hora, cujo faturamento publicitário é relativamente baixo em virtude provavelmente de seu alcance mormente regional, obtiveram desempenho condizente com a perspectiva de que os meios tradicionais ainda respondem pela maior parte do bolo publicitário dedicado ao setor dos jornais impressos.

Tabela 6 - Concentração de investimentos do setor publicitário

\begin{tabular}{c|c|c}
\hline & Faturamento publicitário & Concentração de investimentos \\
\hline O Estado de S. Paulo & $3.109 .616,58$ & 13,17 \\
\hline Folha de S. Paulo & $3.303 .514,37$ & 11,16 \\
\hline O Globo & $1.336 .043,89$ & 5,07 \\
\hline Zero Hora & $311.028,23$ & 1,68 \\
\hline O Dia & $333.724,53$ & 5,77 \\
\hline Extra & $767.291,37$ & 3,22 \\
\hline Meia Hora & $274,153,86$ & 1,77 \\
\hline Super Notícia & $198.556,35$ & 0,66 \\
\hline
\end{tabular}

Fonte: Dados cedidos pelo Ibope e contrastados com dados do IVC. Obs.: Unidades: milhares de reais (R\$mil) por exemplares.

Por fim, vale acrescentar que Belisário (2014, p. 72) descreve que alguns pesquisadores da área têm apostado em uma mudança de perfil dos jornais populares, que estariam deixando de lado parte do sensacionalismo presente nas décadas de 1960 e 1970, para incorporar a prestação de serviço e a "busca pela credibilidade". Nós, contudo, destacamos que essa posição não reflete nossa percepção 
sobre o fenômeno da "tabloidização" no Brasil. Em que pesem as mudanças econômicas recentes e a tentativa dos jornais populares de dialogarem com novas necessidades do público leitor, o jornalismo popular que aqui tratamos de modo indiscriminado como uma imprensa tabloide é fértil em produzir situações espirituosas. Neste sentido, o humor tem sido importante válvula de escape para tornar mais leve o noticiário. E, como vimos, a popularidade de temas como notícias policiais, esportes ou fofocas não está apenas expressa no segmento de leitores de jornais populares. Este jornalismo de fait divers explora sensações que, sem dúvida, não se resumem a crimes, sexo e violência, mas é perpassado pela dimensão do escândalo e da crise, mesmo quando atua como prestador de serviço.

\section{Considerações finais}

Até onde conseguimos depreender, a "tabloidização" brasileira segue uma linha alternativa em relação a outras partes do mundo, em particular em relação aos países do Norte, cujas diferenças marcadas entre o modelo editorial e econômico dos quality papers e o modelo dos tabloides, assim como as limitações à propriedade cruzada dos meios, implicam uma perspectiva dicotômica que percebe os tabloides como "oponentes" dos jornais de prestígio - ora os subestimando, ora os enaltecendo. $\mathrm{O}$ crescimento experimentado pelo segmento de jornais populares no Brasil somente se equipara, obviamente se guardando as devidas proporções, ao contexto de países como a África do Sul, a China e a Índia. O modelo econômico da África do Sul é, entre todos, o que mais se aproxima da solução brasileira, em que as empresas proprietárias de jornais têm investido em uma espécie de "venda casada", lançando e promovendo veículos com públicos-alvo de distintos estratos socioeconômicos, de modo a atuarem de forma complementar no mercado. A esse respeito, Belisário (2014, p. 74) acrescenta que "essas organizações [os conglomerados midiáticos], por motivos mercadológicos, têm buscado, mesmo em suas versões tradicionais, uma aproximação com os valores-notícia de interesse desse estrato social [popular]". Deixaremos para um outro momento uma análise mais detida sobre 
processos de enquadramento do conteúdo noticioso que possam evidenciar graus de "tabloidização" na imprensa brasileira a partir da própria cobertura dos veículos. Também por razões de espaço não nos aprofundamos sobre a abordagem do humor nos veículos da imprensa popular. Entretanto, acreditamos que uma observação de cunho crítico sobre a economia política do campo já é capaz de elucidar suficientemente questões como as que procuramos apontar nessa etapa de nossa pesquisa, indicando, inclusive, que tabloides e jornais tradicionais têm atuado de mãos dadas para suplantar a perspectiva de crise que o setor tem encarado.

Assim, o jogo de forças entre atores que, em outras regiões do mundo, são encarados como concorrentes, aqui ganha outros contornos. Predizer o que esse cenário nos reserva não é tarefa que nos compete. Entretanto, uma observação importante deve ser feita. Como Ogola e Rodny-Gumede (2014) argumentam sobre o contexto na África do Sul e no Quênia, a concentração de capitais em poucas empresas de comunicação, a despeito de salvaguardar a saúde financeira do sistema midiático local, pode representar um efeito perverso sob uma perspectiva político-econômica, pois garante que as mesmas e poucas empresas sigam dominando o mercado da informação. Em resumo, se, por um lado, temos uma alternativa à crise inteiramente desenhada sob um contexto de peculiaridades desenvolvidas pela experiência brasileira, semelhante à de outros países do eixo Sul-Sul e radicalmente distinta do cenário descrito por pesquisadores atentos aos países do Norte, por outro, essa "solução brasileira" pode ser ineficiente para garantir maior diversidade e acesso à informação, uma vez que consolida e perpetua os mesmos grupos no poder.

Este artigo insere-se no debate sobre a economia política dos meios de comunicação no país, particularmente circunspecta à análise da imprensa escrita. Nosso escopo em apresentar avaliações sobre o atual cenário é também de deslindar o grau de comprometimento político do mercado empresarial de mídia no Brasil (Roudakova, 2009), e, de certa forma, levantar novos elementos para uma compreensão ampliada do panorama de crise e reconfiguração do papel da imprensa na sociedade contemporânea. 


\section{Referências}

ABDALA, Vitor; GIRALDI, Renata. Brasil tem mais de 200 milhões de habitantes, segundo IBGE. Agência Brasil, 29 ago. 2013. Disponível em: <http://memoria.ebc.com.br/agenciabrasil/noticia/201308-29/brasil-tem-mais-de-200-milhoes-de-habitantes-segundoibge >. Acesso em: 18 fev. 2017.

AULETTA, Ken. Citizens Jain: why India's newspaper industry is thriving. The New Yorker, New York, 8 Oct. 2012.

BELISÁRIO, Kátia Maria. De Chicago a Contagem: páginas do cotidiano no popular mais lido no Brasil. 2014. Tese (Doutorado) Universidade de Brasília, Brasília, 2014.

BIRD, S. Elizabeth. Audience demands in a murderous market: tabloidization in U.S. television news. In: SPARKS, Colin; TULLOCH, John (Eds.). Tabloid tales. New York: Rowman \& Littlefield, 2000.

BRASIL. Secretaria de Comunicação Social da Presidência da República. Pesquisa Brasileira de Mídia 2014. Brasília: Secom, 2014. BROCK, George. Out of print: newspapers, journalism and the business of news in the digital age. London: Kogan Page, 2013.

CHAGAS, Viktor. Extra! Extra! (Os jornaleiros e as bancas de jornais como espaço de disputas pelo controle da distribuição da imprensa e da economia política dos meios). 2013. Tese (Doutorado) Fundação Getulio Vargas, Rio de Janeiro, 2013.

. Papel de embrulhar peixe: uma análise sobre o modelo econômico de distribuição dos jornais e seus prognósticos. Contemporânea, v. 12, n. 2, p. 410-427, 2014a.

. Overlapping webs: an analytical model for use in Works on the political economy of printed media. In: IAMCR CONFERENCE, 2014, Hyderabad. Annals... Hyderabad: IAMCR, 2014 b.

CONBOY, Martin. Tabloid Britain: constructing a community through language. London: Routledge, 2006.

DURHAM, Frank. Media ritual in catastrophic time: the populist turn in television coverage of Hurricane Katrina. Journalism, v. 9, n. 1, p. 95-116, 2008. 
ESSER, Frank. "Tabloidization" of news: a comparative analysis of Anglo-American and German press journalism. European Journal of Communication, v. 14, n. 3, p. 291-324, 1999.

FISKE, John. Understanding popular culture. New York: Routledge, 2011.

GLYNN, Kevin. Tabloid culture. Durham; London: Duke University Press, 2000.

GRIPSRUD, Jostein. Tabloidizaton, popular journalism, and democracy. In: SPARKS, Colin; TULLOCH, John (Eds.). Tabloid tales. New York: Rowman \& Littlefield, 2000.

GRUPO DE MÍdIA SÃO PAULO. Mídia Dados 2013. São Paulo: Grupo de Mídia São Paulo, 2013.

HALL, Stuart. Notas sobre a desconstrução do "popular”. In: HALL, Stuart; SOVIK, Liv (Orgs.). Da diaspora: identidades e mediações culturais. Belo Horizonte: UFMG, 2011.

HARRINGTON, Stephen. Popular news in the twenty-first century: time for a news critical approach? Journalism: Theory, Practice \& Criticism, v. 9, n. 3, p. 266-284, 2008.

HARRIS, Nichola Reneé. Tabloidization in the modern American press: a textual analysis and assessment of newspaper and tabloid coverage of the "Runaway Bride" case. 2006. PhD Thesis - Georgia State University, Georgia, 2006.

JOHANSSON, Sofia. Reading tabloids: tabloid newspapers and their readers. Estocolmo: Södertörns Högskola, 2007.

KLEIN, Ulrike. Tabloidized political coverage in the German Bild-Zeitung. In: SPARKS, Colin; TULLOCH, John (Eds.). Tabloid tales. New York: Rowman \& Littlefield, 2000.

KURTZ, Howard. Media Circus: the trouble with America's newspapers. New York: Random House, 1993.

LANGER, John. Tabloid television, popular journalism and the other news. London: Routledge, 2003.

LATTMAN-WELTMAN, Fernando; CHAGAS, Viktor. Insegurança, (re)partidarização e "fogo amigo": a economia política dos meios na Era Lula. In: ENCONTRO ANUAL DA COMPÓS, 22., 2013, Salvador. Salvador: Compós, 2013. 
Mercado futuro: a economia política da (re)

partidarização da imprensa no Brasil. Dados, v. 59, n. 2, p. 323-356, 2016.

LIMA, Anastasia B. Is there a tabloidization of online news? A content analysis of traditional news websites. Gnovis, v. 10, n. 1, 2009. Disponível em: <http://www.gnovisjournal.org/2009/12/22/ there-tabloidization-online-news-content-analysis-traditionalnews-websites/>. Acesso em: 18 fev. 2017.

MCLACHLAN, Shelley; GOLDING, Peter. Tabloidization in the British Press: a quantitative investigation into changes in British newspapers 1952-1997. In: SPARKS, Colin; TULLOCH, John (Eds.). Tabloid tales. New York: Rowman \& Littlefield, 2000.

MEIO \& MENSAGEM. Veículos mais admirados. Meio \& Mensagem, 2014.

MOONEY, Attracta M. Tabloidization and the Irish press media: an analysis of how the Irish independent reacted to the introduction of Irish versions of British tabloids. 2008. Master Dissertation University of Leeds, Leeds, 2008.

NINAN, Sevanti. Headlines from the Heartland: reinventing the Hindi public sphere. Nova Delhi: Sage, 2012.

OGOLA, George; RODNY-GUMEDE, Ylva. The future of quality news journalism and media accountability in South Africa and Kenya. In: ANDERSON; Peter; OGOLA, George; WILLIAMS, Michael (Eds.). The future of quality news journalism. New York: Routledge, 2014.

PIONTEK, Dorota. The tabloidization of political discourse: the Polish case. Central European Journal of Communication, v. 2, p. 275-292, 2011.

RANGANATHAN, Maya; RODRIGUES, Usha M. (Eds.). Indian media in a globalized world. Nova Delhi: Sage, 2010.

RODRIGUES, Usha M. Print media in the era of globalization. In: RANGANATHAN, Maya; RODRIGUES, Usha M. (Eds.). Indian media in a globalized world. Nova Delhi: Sage, 2010. 
ROUDAKOVA, Natalia. Journalism as "prostitution": understanding Russia's reactions to Anna Politkovskaya's murder. Political Communication, v. 26, n. 4, p. 412-429, 2009.

SCHUDSON, Michael. What does public journalism knows about journalism but doesn't know about "public"? In: GLASSER, Theodore L. (Ed.). The idea of public journalism. New York; London: The Guilford Press, 1999.

SOOD, Varun. Danik Jagran sees continued growth. Financial Times, 30 Aug. 2009. Disponível em: <https://www.ft.com/ content/9cf6a624-823a-11de-9c5e-00144feabdc0>. Acesso em: $1^{\circ}$ jan. 2013.

SPARKS, Colin. Introduction. Javnost - The Public, Tabloidization and the Media, v. 5, n. 3, p. 1-5, 1998.

. Introduction: the panic over tabloid news. In: SPARKS, Colin; TULLOCH, John (Eds.). Tabloid tales. New York: Rowman \& Littlefield, 2000.

SPARKS, Colin; DALHGREN, Peter (Eds.). Journalism and popular culture. Califórnia: Sage, 1992.

SPARKS, Colin; TULLOCH, John (Eds.). Tabloid tales. New York: Rowman \& Littlefield, 2000

TULLOCH, John. The eternal recurrence of new journalism. In: SPARKS, Colin; TULLOCH, John. (Eds.). Tabloid tales. New York: Rowman \& Littlefield, 2000.

URIBE, Rodrigo; GUNTER, Barrie. Research note: the tabloidization of British tabloids. European Journal of Communication, v. 19, p. 387-402, 2004.

WASSERMAN, Herman. Tabloid journalism in South Africa: True story! Indianapolis: Indiana University Press, 2010.

\section{Resumo}

As relações entre jornalismo e política são geralmente tratadas a partir de um olhar concentrado na imprensa de prestígio. Pouco ou quase nada é discutido a respeito da dimensão política do jornalismo popular no Brasil. Para adensar esse debate, este trabalho pretende desenvolver: a) um investimento teórico na empregabilidade da categoria "tabloide" e no processo de 
"tabloidização"junto ao cenário brasileiro; b) a análise de questões econômicas e concorrenciais inerentes ao jornalismo popular no Brasil; c) a proposição de uma agenda de pesquisa para o desenvolvimento de um modelo metodológico-epistemológico com vistas à identificação e à distinção de tabloides e quality papers; e, finalmente, d) um breve debate sobre o espaço ocupado pela política e outras editorias no noticiário popular nacional.

Palavras-chave: mídia e política; economia política do jornalismo; jornalismo popular; tabloidização.

\section{Abstract}

Journalism and politics have their ties often examined from a prestige press perspective. Little or nothing is discussed about the political dimension of popular journalism in Brazil.

To make this debate more consistent, this paper aims to develop: a) a theoretical investment on the adequacy of the category "tabloid" and in the process of "tabloidization" before the Brazilian media scene; $b$ ) an analysis of economic and competitive issues inherent to popular journalism in Brazil; c) a proposal of a research agenda for the development of a methodological and epistemological model to identify and distinguish tabloid and quality papers; and finally d) a brief discussion on space occupied by the political section before others in Brazilian popular news coverage.

Keywords: media and politics; political economy of journalism; popular journalism; tabloidization.

Recebido em 5 de outubro de 2015. Aprovado em 17 de janeiro de 2017. 